\section{Basic and Applied Ecology}

www.elsevier.com/locate/baae

\title{
Economic gain, stability of pollination and bee diversity decrease from southern to northern Europe
}

\author{
Sara Diana Leonhardt ${ }^{\mathrm{a}, *}$, Nicola Gallai ${ }^{\mathrm{b}}$, Lucas Alejandro Garibaldic ${ }^{\mathrm{c}}$, Michael Kuhlmann ${ }^{\mathrm{d}}$, \\ Alexandra-Maria Klein ${ }^{\mathrm{a}, \mathrm{e}}$ \\ ${ }^{a}$ Institute of Ecology, Ecosystem Functions, Leuphana University of Lüneburg, Scharnhorststraße 1, 21335 Lüneburg, Germany \\ ${ }^{\mathrm{b}}$ Ecole Nationale de Formation Agronomique ENFA, bureau 24, bâtiment 14 2, Route de Narbonne, 31326 Castanet-Tolosan, France \\ 'Sede Andina, Universidad Nacional de Río Negro (UNRN) and Consejo Nacional de Investigaciones Científicas y Técnicas (CONICET), \\ Mitre 630, CP 8400, San Carlos de Bariloche, Río Negro, Argentina \\ ${ }^{\mathrm{d}}$ Department of Life Sciences, Natural History Museum, Cromwell Road, London SW7 5BD, United Kingdom \\ ${ }^{\mathrm{e}}$ Institute of Earth and Environmental Sciences, University of Freiburg, Tennenbacherstraße 4, 79106 Freiburg, Germany
}

Received 10 December 2012; accepted 25 June 2013

\begin{abstract}
Bees are in decline potentially leading to reduced pollination and hence production of insect-pollinated crops in many countries. It is however still unclear whether the consequences of pollinator shortages differ among countries with different environmental and societal conditions. Here, we calculated economic gains attributed to insect (particularly bee) pollination (EVIP) as well as their contribution to the total value of crop production (vulnerability), and analyzed their temporal trends and inter-annual variability from 1991 to 2009 for each country of the European Union (EU). To understand which factors drive country-specific differences in pollinator dependency and stability of insect-dependent crop yields, we further asked whether EVIP, vulnerability and stability of yields were influenced by a country's climate, the number of wild bee species and/or managed honeybee hives per country, and (agricultural) gross domestic product (GDP).

Across Europe, crop pollination by insects accounted for 14.6 [ \pm 3.3$]$ billion EUR annually (EVIP), which equaled $12( \pm 0.8) \%$ of the total economic value of annual crop production. Gains strongly varied among countries. Both EVIP and vulnerability increased (and the inter-annual variation of vulnerability decreased) significantly from the colder northern to the warmer Mediterranean EU countries, in parallel with increases in the number of wild bee species. Across years, economic importance of pollination increased in all but three EU countries. Apples were the most important insect-pollinated crop in the EU, accounting for $16 \%$ of the EU's total EVIP. Our results show that whereas dependency on insect pollination increased from the colder north to the warmer south, variation in economic gain from insect pollination decreased, indicating that Mediterranean countries had more stable yields of pollinator-dependent crops across years and thus more reliable gains from pollination services.
\end{abstract}

\section{Zusammenfassung}

Seit einigen Jahren nimmt die Bienendiversität in zahlreichen Ländern ab. Mögliche Folgen dieses Artenrückgangs sind eine Abnahme der Bestäubungsleistung und ein dadurch verringerter Ertrag bei insektenbestäubten Kulturpflanzen. Unklar ist, ob die Bedeutung der Bestäuberleistung und damit deren Auswirkung auf Ernteerträge mit den gesellschaftlichen und/oder Umweltbedingungen eines Landes zusammenhängen. In der hier vorgelegten Studie berechneten wir für die Länder der Europäischen Union (EU) den Wirtschaftsgewinn, welcher durch Bestäubungsleistungen (insbesondere von Bienen) erzielt

\footnotetext{
*Corresponding author. Tel.: +494131677 2185; fax: +4941316772849.

E-mail address: leonhardt@leuphana.de (S.D. Leonhardt).
} 
wird (Wirtschaftswert der Insektenbestäubung, WWIB), sowie dessen Anteil am Gesamtgewinn aus dem Ertrag von allen Kulturpflanzen. Aus letzterem ergibt sich ein Wert, der dem landesspezifischen „Risiko” von Wirtschaftseinbußen durch einen Bestäuberrückgang entspricht. Darüber hinaus untersuchten wir jahreszeitliche Schwankungen von WWIB und dem Risikowert sowie deren Entwicklung über die Jahre 1991 bis 2001. Um besser zu verstehen, welche Faktoren landesspezifische Unterschiede in der Abhängigkeit von Bestäubungsleistungen sowie der Stabilität von Ernteerträgen bei insektenbestäubten Kulturpflanzen verursachen, analysierten wir die Zusammenhänge zwischen WWIB, Risiko und Etragsstabilität mit dem Klima, der Bienendiversität und Honigbienenvölkeranzahl jedes EU Landes sowie des Teils seines Bruttoinlandproduktes, der auf den Agrarsektor entfällt.

Die Bestäubung von Kulturpflanzen durch Insekten machte innerhalb der gesamten EU jährlich 14.6 [ \pm 3.3$]$ Milliarden EUR (WWIB) aus, was einem Anteil von $12( \pm 0.8) \%$ des durchschnittlichen Jahesgesamtgewinns aus der Ernte von Kulturpflanzen entspricht. Die Gewinne waren von Land zu Land stark unterschiedlich. Sowohl WWIB als auch der Risikowert nahmen von den kälteren nördlichen Ländern zu den wärmeren Mittelmeerstaaten hin zu, ebenso wie die Bienendiversität, während jährliche Schwankungen des Risikowerts abnahmen. Die wirtschaftliche Bedeutung der Bestäubung nahm von 1991 bis 2001 in fast allen EU-Ländern zu. Äpfel machten, als wichtigste in der EU produzierte Feldfrucht, 16\% des auf Bestäubungsleistungen basierenden Gesamtgewinns aus. Unsere Berechnungen verdeutlichen, dass sowohl die Abhängigkeit von der Insektenbestäubung als auch die Ertragsstabilität vom kalten europäischen Norden zu den Mittelmeerländern hin zunimmt. Mittelmeerstaaten erzielen folglich stabilere Gewinne aus insektenbestäubten Kulturpflanzen und damit aus Bestäubungsleistungen.

() 2013 Gesellschaft für Ökologie. Published by Elsevier GmbH. All rights reserved.

Keywords: Climate; Crop pollination; Ecosystem service; Economic vulnerability; Honeybees; Stability; Wild bees

\section{Introduction}

In recent years, different pollinator taxa have declined in several countries (Banaszak 1995; Biesmeijer et al. 2006; Bommarco, Lundin, Smith, \& Rundlöf 2011; Cameron et al. 2011; Potts, Biesmeijer, et al. 2010; Thomas et al. 2004; Winfree, Aguilar, Vazquez, LeBuhn, \& Aizen 2009), and pollinators often represent a limiting factor in many agroecosystems (Klein et al. 2007). This decline is likely to continue, while, at the same time, the area of pollinatordependent crop production is increasing (Aizen, Garibaldi, Cunningham, \& Klein 2008; Calderone 2012). Causes of the decline are manifold, comprising agricultural intensification and habitat conversion (Aizen \& Feinsinger 2003; Brosi, Daily, Shih, Oviedo, \& Duran 2008; Kremen, Williams, \& Thorp 2002; Quintero, Morales, \& Aizen 2010; Steffan-Dewenter \& Tscharntke 1999), the use of pesticides (Brittain \& Potts 2011; Johansen 1977), invasive species (Ghazoul 2004; Schweiger et al. 2010), introduced pathogens (Cameron et al. 2011) and climate change (Hegland, Nielsen, Lázaro, Bjerknes, \& Totland 2009). Given the importance of wild and domesticated pollinators for many wild and crop plant species, an increasing number of researchers warn against the potential yield losses that agriculture faces when loosing these pollinators, due to insufficient pollination and hence a reduction in or even entire failure of seed set (Garibaldi, Steffan-Dewenter, et al. 2011; Klein et al. 2007; Kremen et al. 2002, 2007; Steffan-Dewenter, Potts, \& Packer 2005). In fact, Garibaldi, Aizen, Klein, Cunningham, and Harder (2011) demonstrated that, between 1961 and 2008 , the mean growth and stability of crop yields decreased with pollinator dependency, suggesting that the correlation between pollinator density, crop yield and hence monetary gain from pollinator-dependent crops is positive. Through declining pollinator abundance and diversity pollination as an important regulating ecosystem service is at risk, ultimately affecting food production (Garibaldi, Steffan-Dewenter, et al. 2011; Klein et al. 2007; Kremen et al., 2002, 2007; SteffanDewenter et al. 2005). As nations depend on the production of crops to feed their people and to increase their gross domestic product (GDP) by exporting goods, worldwide economic losses resulting from a lack of animal pollination are estimated to make up for 153 billion EUR or 9.5\% of the world's crop production for human food in 2005 (Gallai, Salles, Settele, \& Vaissière 2009), or 291 billion EUR if the purchasing power parity of countries is considered (Lautenbach, Seppelt, Liebscher, \& Dormann 2012). Moreover, all over the world, agricultural production increasingly depends on pollination (Aizen et al. 2008; Garibaldi, Aizen, et al. 2011), a trend that can be highly country- and region-specific (Lautenbach et al. 2012) but points to a further increasing risk of loosing this essential service provided by animal pollinators.

Global or regional patterns of the economic dependence on pollinators, albeit important, may hide heterogeneous responses of different countries, which is essential information needed to facilitate adequate political and management decisions. Although most political decisions with regard to agriculture are made at country level, the economic value of pollination services has so far only rarely been estimated for individual countries. Also, analyzing among-country spatial variation in the overall economic dependence on pollination services, its temporal trends as well as the factors correlated with variation is important to understand the geographical, environmental and socio-economic factors influencing this dependency. Following Gallai et al.'s (2009) approach, we therefore estimate the monetary gain (and its annual variation) that individual countries in the European Union (EU) 
obtain from pollination services (i.e., economic value of insect pollination, EVIP) as well as its proportion of a country's total economic value of the agricultural sector. Gallai et al. (2009) consider the latter a measure for a country's vulnerability to pollinator shortages. Gains from pollination services and vulnerability hence represent a country's dependence on animal pollination. Note that insects and especially bees (wild bees and managed honeybees) represent the most important animal pollinators in Europe and that a country's EVIP can be primarily attributed to pollination by bees and particularly unmanaged wild bees (Breeze, Bailey, Balcombe, \& Potts 2011; Klein et al. 2007).

To better understand which factors drive country-specific differences in pollinator dependence, we analyze whether EVIP and vulnerability as well as their coefficients of variation (which represents the stability of yields and hence pollination services) correlate with a country's climate (mean monthly temperature and rainfall), the number of wild bee species, the number of managed honeybee colonies, and the gross domestic product contributed by a country's agricultural sector (agricultural GDP). We hypothesize that the dependency on pollinating insects and hence the economic consequences of a pollinator shortage varied among countries because they face largely different climatic and economic conditions, with the climatically colder, northern and central European countries often representing the more industrialized and less agricultural ones. Moreover, whereas the number of managed honeybee hives is likely equal across Europe, the climatically warmer southern European countries harbor more wild pollinator species (Kuhlmann et al. 2012). Its warmer climate is further more suitable for growing fruit crops (e.g., peaches, citrus fruits, watermelon, almond) that depend on pollinators. We therefore predict that the warmer southern European countries are more affected by and are more vulnerable to pollinator losses than northern countries, but that yields from pollinator-dependent crops are more stable in the Mediterranean south due to a higher richness of bees. We finally list those crops that make up the majority of insect-pollinator dependent crops in European countries.

\section{Materials and methods}

\section{Economic value of insect pollination}

The total economic value of insect pollination (EVIP) of crops used for food production in each EU country from 1991 to 2009 was calculated following the equation suggested by Gallai et al. (2009):

$\mathrm{EVIP}=\sum_{i=1}^{I} \sum_{c=1}^{C} \sum_{t=1}^{T}\left(P_{i c t} \times Q_{i c t} \times D_{i}\right)$

where $P_{i c t}$ is the unitary producer price of crop $i$ for country $c$ for year $t, Q_{i c t}$ the overall quantity of crop $i$ for country $c$ at time $t$, and $D_{i}$ the dependence ratio of crop $i$ on insect pollinators.

The crops $i$ used for the calculations comprised direct and commodity crops listed on the Food and Agriculture Organization (FAO) website (http://www.fao.org). Direct crops were listed individually with their production rates, whereas commodity crops represent an aggregation of different crops for which production rates are pooled (Gallai et al. 2009). The latter were excluded from the calculation of EVIP, because neither production nor price data were available for the individual crops, which the commodities comprised. Moreover, crops within commodities often depend on pollinators to a variable degree, rendering the use of average dependencies rather problematic.

For $Q_{i}$ and $P_{i}$, we used the production and price data provided by FAO, respectively. Production is given in tons and price in US dollars per ton. The FAO database generally provides a large data set, but production or price figures are missing for some years and for some countries. Where production values for the year $t$ of the country $c$ were missing we could not calculate EVIP. If values for prices, but not for production were missing for a crop $i^{*}$ in the country $c^{*}$ at time $t^{*}$, we used the 'moving average methodology' to calculate the price at this particular year $\left(t^{*}\right): p_{t^{*}} c^{*} i^{*}=$ $\left(P_{t^{*}-3}+P_{t^{*}-2}+P_{t^{*}-1}\right) / 3$. If the price was missing for a longer period, we used the weighted mean of European prices for this crop $i^{*}$ :

$p w_{i *}=\frac{\sum_{c=1}^{C}\left(P_{c} \times Q_{c}\right)}{\sum_{c=1}^{C}\left(Q_{c}\right)}$

If European producer price information was unavailable for crop $i^{*}$, we used world prices. However, we were unable to find any prices for peppermint and therefore excluded this crop from our calculations.

The dependence ratio $\left(D_{i}\right)$ was based on the five levels defined by Klein et al. (2007: Appendix 1 and 2): essential (0.95), great $(0.65)$, modest $(0.25)$, little $(0.05)$ and none (0). Dependencies for those crops for which pollinator dependency levels were not provided by Klein et al. (2007) were categorized based on the information provided by the Pollination Information Management System (PIMS: http://www.internationalpollinatorsinitiative.org/jsp/ pollneeds/pollneeds.jsp), by Delaplane and Mayer (2000), by McGregor (1976) and by Miller et al. (2005). Crops that are produced vegetatively (e.g., potato) and depend on pollinators for breeding only (if at all) were considered 'non-dependent'. Citrus spp. were generally considered to depend little on pollination. No reliable information on pollinator dependency levels could be found for castor oil seed (Ricinus communis L.), hazelnuts (Corylus avellana L.), peppermint (Mentha piperita $\mathrm{L}$.) and pistachios (Pistacia vera L.).

EVIP was analyzed for a time period, $t$, from 1991 to 2009, because the FAO only contained producer prices from 1991 onwards (historical data from 1966 to 1990 was provided in the price archive, but the two data sets 
were not always comparable, see http://www.fao.org for more details). Monetary values for EVIP were subsequently calculated in euros using the average exchange rate of 1991 and 2009 (http://fxtop.com: 1 USD =0.72 EUR).

\section{Vulnerability}

We extended our analysis by calculating the vulnerability of each country using the equation of Gallai et al. (2009). Vulnerability was defined as the ratio of EVIP and the total economic value of crop production (TEV), with time (in years) included as additional variable:

$\mathrm{VR}=\frac{\sum_{i=1}^{I} \sum_{c=1}^{C} \sum_{t=1}^{T}\left(P_{i c t} \times Q_{i c t} \times D_{i}\right)}{\sum_{i=1}^{I} \sum_{c=1}^{C} \sum_{t=1}^{T}\left(P_{i c t} \times Q_{i c t}\right)}=\frac{\mathrm{EVIP}}{\mathrm{TEV}}$,

Hence, higher vulnerability basically indicates a strong dependence of the agricultural GDP on insect pollination and suggests that the agricultural sector is highly vulnerable to a pollinator decline.

\section{Wild bee and honeybee data}

Numbers of managed honeybee colonies per country were obtained from the FAO (http://www.fao.org) and averaged for 1991-2009. The data had been compiled and provided to the FAO by the countries' governments. Data for the number of wild bee species per country was retrieved from the online database "Checklist of Western Palaearctic Bees" (Kuhlmann et al. 2012). The checklist is a compilation of taxonomic and distribution data on country level that is largely based on information assembled for the "Discover Life bee species guide and world checklist (Hymenoptera: Apoidea: Anthophila)" (Ascher \& Pickering 2012). It contains regularly updated information from both published and unpublished sources including data from a whole range of private and public collections that are provided by European wild bee experts. Thus, the checklist reflects the current state of knowledge on the taxonomy and distribution of western Palaearctic bees making it a prime source of information. Details on the information sources used for the compilation of the bee data can be found in Kuhlmann et al. (2012) and Ascher and Pickering (2012).

In the western Palaearctic region, 3330 bee species are known so far with almost 2000 species recorded for Europe (Kuhlmann 2012; Kuhlmann et al. 2012). However, wild bees have been unevenly recorded across Europe. Consequently, the species numbers per country used for our data analysis (see Appendix A: Table 1) did not always reflect the expected actual species richness. For the EU the number of species recorded from Portugal, Bulgaria and Cyprus in particular were lower than to be expected (Kuhlmann, pers. observ.), but the figures could be assumed to still reflect the real dimensions of species richness. This certainly was not the case for Malta, which is still seriously under-collected and was hence excluded from the analysis.

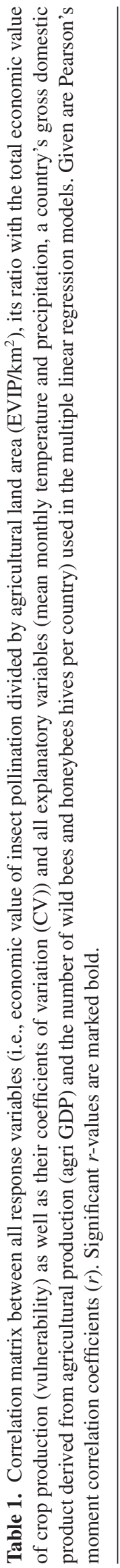

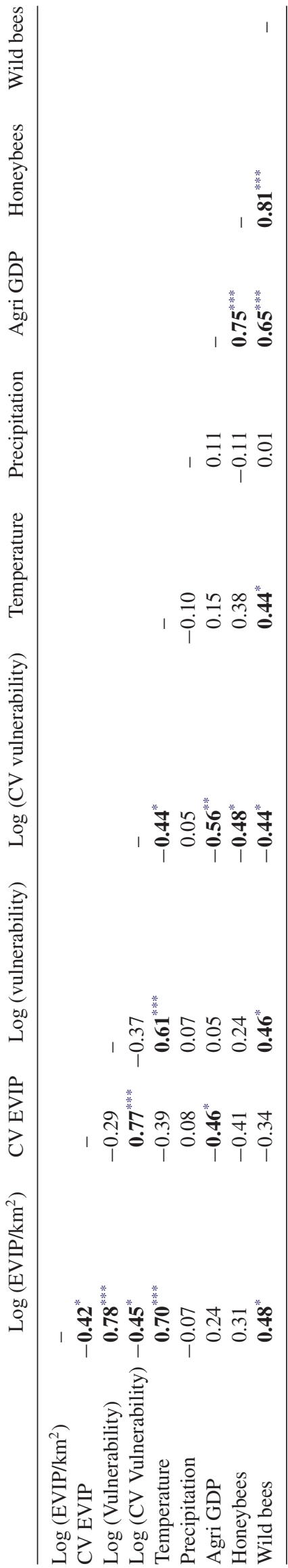

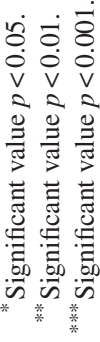


Table 2a. Results for multiple regression linear models of the economic value of insect pollination corrected for agricultural land area $\left(\mathrm{EVIP} / \mathrm{km}^{2}\right)$, its ratio with the total economic value of crop production (vulnerability) as well as their coefficients of variation $(\mathrm{CV})$. Explanatory variables used were the number of wild bee species (bee diversity), the mean monthly temperature and precipitation and the gross domestic product contributed by the agricultural sector (agri GDP) of each country of the European Union. Given are degrees of freedom $(D F)$, adjusted $R^{2}$-values $\left(R^{2}\right), F$-values and $p$-values for all variables; significant $p$-values are marked in bold.

\begin{tabular}{|c|c|c|c|c|c|}
\hline Variable tested & $D F$ & $R^{2}$ & Factors & $F$ & $p$ \\
\hline $\log \left(\mathrm{EVIP} / \mathrm{km}^{2}\right)$ & 1.19 & 0.28 & $\begin{array}{l}\text { Bee diversity } \\
\text { Temperature } \\
\text { Precipitation } \\
\text { Agri GDP }\end{array}$ & $\begin{array}{l}6.32 \\
6.41 \\
0.11 \\
0.29\end{array}$ & $\begin{array}{l}\mathbf{0 . 0 2} \\
\mathbf{0 . 0 2} \\
0.74 \\
0.60\end{array}$ \\
\hline CV EVIP & 1.19 & 0.16 & $\begin{array}{l}\text { Bee diversity } \\
\text { Temperature } \\
\text { Precipitation } \\
\text { Agri GDP }\end{array}$ & $\begin{array}{l}1.98 \\
1.52 \\
0.04 \\
4.93\end{array}$ & $\begin{array}{l}0.18 \\
0.23 \\
0.84 \\
\mathbf{0 . 0 4}\end{array}$ \\
\hline Vulnerability & 1.19 & 0.24 & $\begin{array}{l}\text { Bee diversity } \\
\text { Temperature } \\
\text { Precipitation } \\
\text { Agri GDP }\end{array}$ & $\begin{array}{l}5.43 \\
4.53 \\
0.80 \\
0.58\end{array}$ & $\begin{array}{l}\mathbf{0 . 0 3} \\
\mathbf{0 . 0 5} \\
0.38 \\
0.46\end{array}$ \\
\hline Log (CV vulnerability) & 1.19 & 0.37 & $\begin{array}{l}\text { Bee diversity } \\
\text { Temperature } \\
\text { Precipitation } \\
\text { Agri GDP }\end{array}$ & $\begin{array}{l}6.11 \\
5.94 \\
0.25 \\
5.45\end{array}$ & $\begin{array}{l}\mathbf{0 . 0 2} \\
\mathbf{0 . 0 2} \\
0.62 \\
\mathbf{0 . 0 3}\end{array}$ \\
\hline
\end{tabular}

\section{Data on climate, areas used for agriculture and gross domestic product (GDP)}

Data on the mean annual temperatures as well as the amount of rainfall between 1991 and 2009 was obtained from the Worldclim - Global Climate database (http://www.worldclim.org/bioclim). The Worldclim database provides averages for the monthly mean temperature and precipitation between 1965 and 1978. Figures on gross domestic products (GDP) contributed by the agricultural sector, between 1991 and 2010, as well as the area in each country that is used for agriculture were downloaded from the World Bank database (http://data.worldbank.org).

\section{Statistical analyses}

We tested how annual EVIP and vulnerability as well as their coefficients of variation $(\mathrm{CV}$ - to account for

Table 2b. Results for multiple regression linear models performing the same analysis as in Table 2a with the factor "bee diversity" replaced by "honeybees". All else being equal.

\begin{tabular}{|c|c|c|c|c|c|}
\hline Variable tested & $D F$ & $R^{2}$ & Factors & $F$ & $P$ \\
\hline $\log \left(\mathrm{EVIP} / \mathrm{km}^{2}\right)$ & 1.15 & 0.5218 & $\begin{array}{l}\text { Honeybees } \\
\text { Temperature } \\
\text { Precipitation } \\
\text { Agri GDP }\end{array}$ & $\begin{array}{r}2.41 \\
16.74 \\
4.27 \\
1.32\end{array}$ & $\begin{array}{c}0.14 \\
<\mathbf{0 . 0 0 1} \\
0.06 \\
0.27\end{array}$ \\
\hline CV EVIP & 1.15 & 0.1529 & $\begin{array}{l}\text { Honeybees } \\
\text { Temperature } \\
\text { Precipitation } \\
\text { Agri GDP }\end{array}$ & $\begin{array}{l}2.75 \\
1.22 \\
0.21 \\
3.25\end{array}$ & $\begin{array}{l}0.12 \\
0.29 \\
0.65 \\
0.09\end{array}$ \\
\hline Vulnerability & 1.15 & 0.3521 & $\begin{array}{l}\text { Honeybees } \\
\text { Temperature } \\
\text { Precipitation } \\
\text { Agri GDP }\end{array}$ & $\begin{array}{l}1.08 \\
8.59 \\
4.04 \\
0.61\end{array}$ & $\begin{array}{l}0.32 \\
\mathbf{0 . 0 1} \\
0.06 \\
0.45\end{array}$ \\
\hline Log (CV vulnerability) & 1.15 & 0.3438 & $\begin{array}{l}\text { Honeybees } \\
\text { Temperature } \\
\text { Precipitation } \\
\text { Agri GDP }\end{array}$ & $\begin{array}{l}5.87 \\
4.81 \\
0.17 \\
3.10\end{array}$ & $\begin{array}{l}\mathbf{0 . 0 3} \\
\mathbf{0 . 0 4} \\
0.68 \\
0.10\end{array}$ \\
\hline
\end{tabular}


inter-annual variation) vary with climate (temperature and precipitation), the number of wild bee species, the average number of honeybee colonies and agricultural GDP of each EU country, using multiple linear regression models. The following variables were correlated with the countries' agricultural area: EVIP (Pearson's moment correlation: $r=0.76$, $p<0.001)$, honeybee hive numbers $(r=0.80, p<0.001)$ and numbers of wild bee species $(r=0.62, p<0.01)$. The numbers of managed honeybee hives and wild bee species further correlated with each other (see Tables $2 a$ and $2 b$ ), rendering models including both of these variables problematic. The EVIP of each country was divided by its agricultural area (in $\mathrm{km}^{2}$ ) to separate the effect of area from climatic and economic effects.

To test for spatial autocorrelation of residuals, we visually assessed the data using a variogram based on the residuals of the linear model and Euclidean distances among countries ( $R$ software, gstat package, variogram function). The variogram did not show any autocorrelation of residuals.

Where necessary we $\log _{10}$ transformed the response variables to achieve normality and homogeneity of variances. All statistical tests were run in R ( $R$ Development Core Team 2012). Results are given in Tables 1, 2a and 2b.

\section{Results}

\section{Economic value of insect pollination (EVIP)}

In total, insect pollination services accounted for 14.6 [ \pm 3.3$]$ billion EUR annually in the EU, which equals $12 \pm 0.8 \%$ of the total economic value of annual crop production (TEV: $121.0 \pm 23.3$ EUR) (Table 3). EVIP was highest in Italy with $2.8( \pm 0.4)$ billion EUR followed by Spain ( $2.2 \pm 0.5$ billion EUR), France ( $2.1 \pm 0.5$ billion EUR) and Germany (1.6 \pm 0.5 billion EUR) (Table 3 and Fig. 1A). Malta had the lowest EVIP value $(7.5 \pm 1.1$ million EUR, Table 3). However, when we accounted for agricultural area, EVIP/ $/ \mathrm{km}^{2}$ was highest for Malta $\left(73,593.9 \mathrm{EUR} / \mathrm{km}^{2}\right.$ agricultural area) and lowest for Ireland (664.4 EUR/ $\mathrm{km}^{2}$ ). Between 1991 and 2009, gain from pollination services increased in all but three EU countries (Italy, Finland and Hungary, Table 3), resulting in a general increase of the economic value of pollination across Europe (10-100\% category) (Fig. 2). Apples were the most common pollinatordependent crop produced by 26 EU countries and ranked among the three most pollinator-dependent crops in 18 European countries (Table 3). Apples also accounted for $16 \%$ of the EU's EVIP and made up at least $1 \%$ of a country's total crop production in $19 \mathrm{EU}$ countries (see Appendix A: Table 2) with Germany, Italy, France and Poland representing the major apple producers (all producing more than on average 1 million tons of apples per year, see FAO). Thus, apples by far exceeded the importance of any other crop, e.g., peaches and nectarines (which accounted for overall 9\% of the EU's
(A)

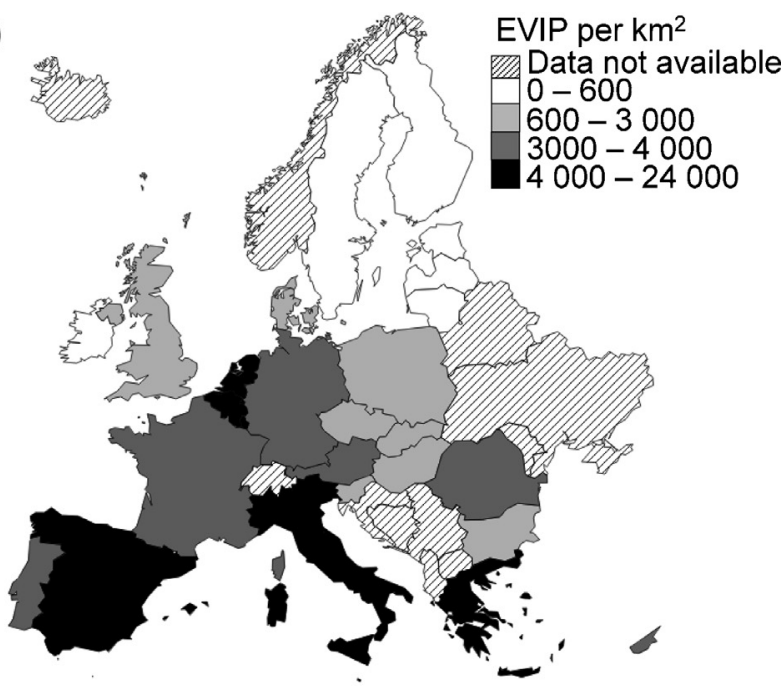

(B)

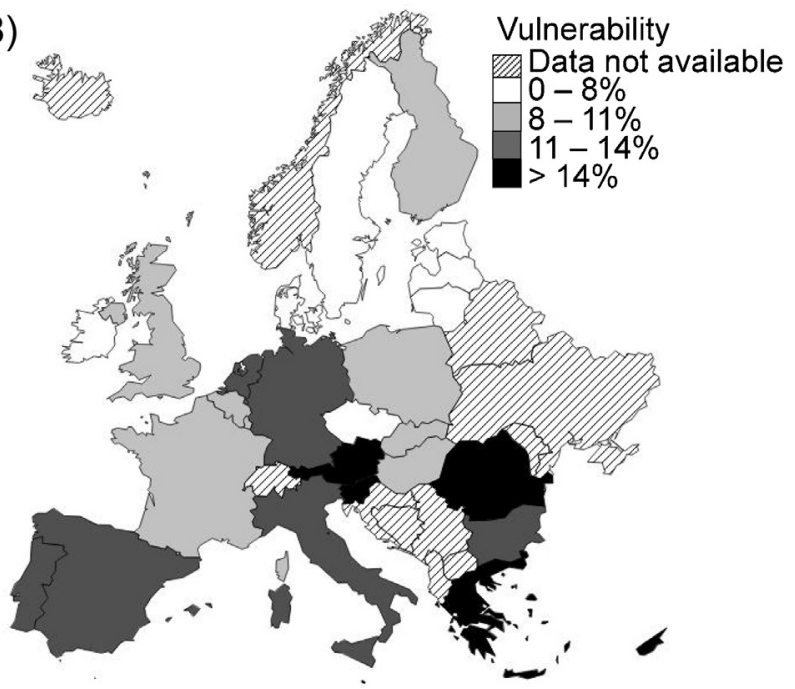

Fig. 1. Economic value of insect pollination (EVIP/ $\mathrm{km}^{2}$ agricultural area) (A) and vulnerability (B) for each country of the European Union between 1991 and 2009.

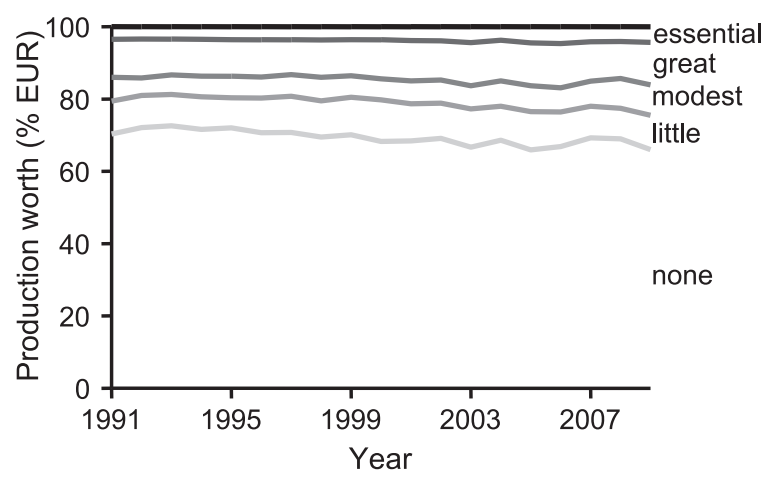

Fig. 2. Percentage of economic value of insect pollination (EVIP) of the total value of crop production in the European Union attributed to crops with different pollination dependency levels (as specified in Klein et al. 2007: Appendix 1 and 2). 
Table 3. Average annual economic value of insect pollination (EVIP) $[ \pm \mathrm{SD}]$ (in billion EUR), contribution [ \pm SD] (in \%) of EVIP to total economic value of crop production (vulnerability, VR), average EVIP corrected for agricultural area (in EUR/km ${ }^{2}$ ), annual growth rates $(\Delta$ ) of EVIP [median \pm interquartile ranges] and the three most pollinator dependent crops (in terms of monetary gain from pollination services) of each EU country between 1991 and 2009.

\begin{tabular}{|c|c|c|c|c|c|}
\hline Country & $\mathrm{EVIP} \pm \mathrm{SD}$ & VR & $\mathrm{EVIP} / \mathrm{km}^{2}$ & $\Delta \mathrm{EVIP}$ & Major pollinator-dependent crops \\
\hline Austria & $0.20 \pm 0.07$ & $19 \pm 4$ & 8313 & $1.01 \pm 0.18$ & Apples, cherries, pears \\
\hline Belgium-Luxembourg & $0.35 \pm 0.24$ & $11 \pm 3$ & 16,856 & $1.08 \pm 0.35$ & Pears, apples, cabbages \\
\hline Bulgaria & $0.09 \pm 0.03$ & $12 \pm 2$ & 2237 & $1.14 \pm 0.51$ & $\begin{array}{l}\text { Sunflower seeds, cucumbers and gherkins, } \\
\text { watermelons }\end{array}$ \\
\hline Cyprus & $0.03 \pm 0.004$ & $20 \pm 2$ & 25,922 & $1.01 \pm 0.13$ & Watermelons, cucumbers and gherkins, apples \\
\hline Czech Republic & $0.09 \pm 0.04$ & $7 \pm 3$ & 2935 & $1.02 \pm 0.22$ & Rapeseed, apples, cucumbers and gherkins \\
\hline Denmark & $0.06 \pm 0.02$ & $6 \pm 1$ & 3272 & $1.01 \pm 0.25$ & Rapeseed, carrots and turnips, cabbages \\
\hline Estonia & $0.01 \pm 0.01$ & $8 \pm 4$ & 1261 & $1.03 \pm 0.40$ & Cabbages, rapeseed, cucumbers and gherkins \\
\hline Finland & $0.05 \pm 0.01$ & $10 \pm 1$ & 2899 & $0.98 \pm 0.15$ & $\begin{array}{l}\text { Cucumbers and gherkins, carrots and turnips, } \\
\text { rapeseed }\end{array}$ \\
\hline France & $1.48 \pm 0.33$ & $9 \pm 1$ & 5612 & $1.01 \pm 0.19$ & Apples, peaches and nectarines, rapeseed \\
\hline Germany & $1.13 \pm 0.39$ & $13 \pm 2$ & 9004 & $1.13 \pm 0.21$ & Apples, cabbages, rapeseed \\
\hline Greece & $0.84 \pm 0.11$ & $15 \pm 2$ & 14,147 & $1.00 \pm 0.14$ & Seed cotton, peaches and nectarines, watermelons \\
\hline Hungary & $0.16 \pm 0.05$ & $9 \pm 1$ & 3553 & $0.99 \pm 0.20$ & Sunflower seeds, apples, sour cherries \\
\hline Ireland & $0.02 \pm 0.01$ & $6 \pm 1$ & 664 & $1.04 \pm 0.29$ & Cabbages, carrots and turnips, apples \\
\hline Italy & $2.02 \pm 0.29$ & $14 \pm 1$ & 18,016 & $0.99 \pm 0.12$ & Apples, peaches and nectarines, pears \\
\hline Latvia & $0.02 \pm 0.01$ & $7 \pm 2$ & 1433 & $1.12 \pm 0.40$ & Cabbages, rapeseed, cucumbers and gherkins \\
\hline Lithuania & $0.03 \pm 0.02$ & $8 \pm 4$ & 1296 & $1.10 \pm 0.50$ & Cabbages, rapeseed, apples \\
\hline Malta & $0.01 \pm 0.001$ & $19 \pm 4$ & 73,594 & $1.02 \pm 0.27$ & Melons, dry onions, cauliflowers and broccoli \\
\hline Netherlands & $0.41 \pm 0.08$ & $12 \pm 2$ & 23,477 & $1.05 \pm 0.16$ & Cucumbers and gherkins, apples, pears \\
\hline Poland & $0.47 \pm 0.17$ & $10 \pm 2$ & 3619 & $1.07 \pm 0.20$ & Cabbages, apples, cucumbers and gherkins \\
\hline Portugal & $0.23 \pm 0.06$ & $13 \pm 1$ & 8230 & $1.06 \pm 0.13$ & Apples, pears, cabbages \\
\hline Romania & $0.57 \pm 0.28$ & $16 \pm 4$ & 5256 & $1.11 \pm 0.23$ & Cabbages, apples, plums and sloes \\
\hline Slovakia & $0.05 \pm 0.02$ & $10 \pm 4$ & 2930 & $1.07 \pm 0.18$ & $\begin{array}{l}\text { Rapeseed, cabbages, pumpkins, squash and } \\
\text { gourds }\end{array}$ \\
\hline Slovenia & $0.03 \pm 0.01$ & $16 \pm 5$ & 7059 & $1.12 \pm 0.41$ & Apples, cabbages, pears \\
\hline Spain & $1.61 \pm 0.39$ & $14 \pm 1$ & 7518 & $1.05 \pm 0.15$ & Peaches and nectarines, melons, apples \\
\hline Sweden & $0.04 \pm 0.01$ & $6 \pm 1$ & 1752 & $1.03 \pm 0.14$ & $\begin{array}{l}\text { Apples, cucumbers and gherkins, carrots and } \\
\text { turnips }\end{array}$ \\
\hline United Kingdom & $0.51 \pm 0.12$ & $11 \pm 1$ & 4009 & $1.01 \pm 0.23$ & Carrots and turnips, cabbages, apples \\
\hline EU total & $14.60 \pm 3.35$ & $12 \pm 1$ & 6948 & $1.03 \pm 0.15$ & \\
\hline
\end{tabular}

total economic value of insect pollination) or cabbages $(8 \%)$ (Table 3 and Appendix A: Table 2).

Gains from insect pollination per year (EVIP corrected for area of production) significantly increased with increasing numbers of wild bee species and increasing mean temperatures (Tables 1, 2a and 2b and Fig. 3A), whereas variation (i.e., coefficients of variation, $\mathrm{CV}$ ) was independent of climate, bee diversity or the number of honeybee hives (Tables 1, 2a and 2b and Fig. 3B). However, variation in EVIP decreased with a country's agricultural GDP (Tables 1, 2a and 2b).

\section{Vulnerability}

Like EVIP, vulnerability of the entire European Union also significantly increased by $116 \%$ between 1991 and 2009 $\left(R^{2}=0.69, p<0.0001\right)$, and was generally high (Fig. 1B). EVIP accounted for more than $15 \%$ of the total gain from agricultural food production in Austria, Cyprus, Greece, Italy, Malta, Romania and Slovenia, whereas only 9 out of
26 countries had a vulnerability below $10 \%$ (Appendix A: Table 2 and Fig. 1B). Climatically warmer countries were more vulnerable than colder ones (Tables 1, 2a and $2 \mathrm{~b}$ and Fig. 3C), but variation in vulnerability across years was lower for warmer than for colder countries (Tables 1, 2a and $2 \mathrm{~b}$ and Fig. 3D). Vulnerability further increased with the number of wild bees, but was independent of the number of managed honeybees (Tables 1, 2a and 2b). Variation in vulnerability in turn decreased with the number of bee species, the number of managed honeybee hives and agricultural GDP (Tables 1, 2a and 2b).

\section{Discussion}

Country-specific estimates of temporal variation in economic gains of insect pollination and their stability (i.e., reverse of variation, $\mathrm{CV}$ ), together with information on the identity of each country's major pollinator-dependent crops 


$\begin{array}{lllllll}\text { AT Austria } & \text { CY Cyprus } & \text { EE Estonia } & \text { HU Hungary } & \text { LV Latvia } & \text { PT Portugal } & \text { SI Slovenia } \\ \text { BE/LU Belgium } & \text { CZ Czech Republic } & \text { ES Spain } & \text { IE Ireland } & \text { MA Malta } & \text { RO Romania } & \text { UK United } \\ \text { Luxembourg } & \text { DE Germany } & \text { FI Finland } & \text { IT Italy } & \text { NL Netherlands } & \text { SE Sweden } & \text { Kingdom } \\ \text { BG Bulgaria } & \text { DK Denmark } & \text { FR France } & \text { LT Lithuania } & \text { PO Poland } & \text { SK Slovakia } & \end{array}$
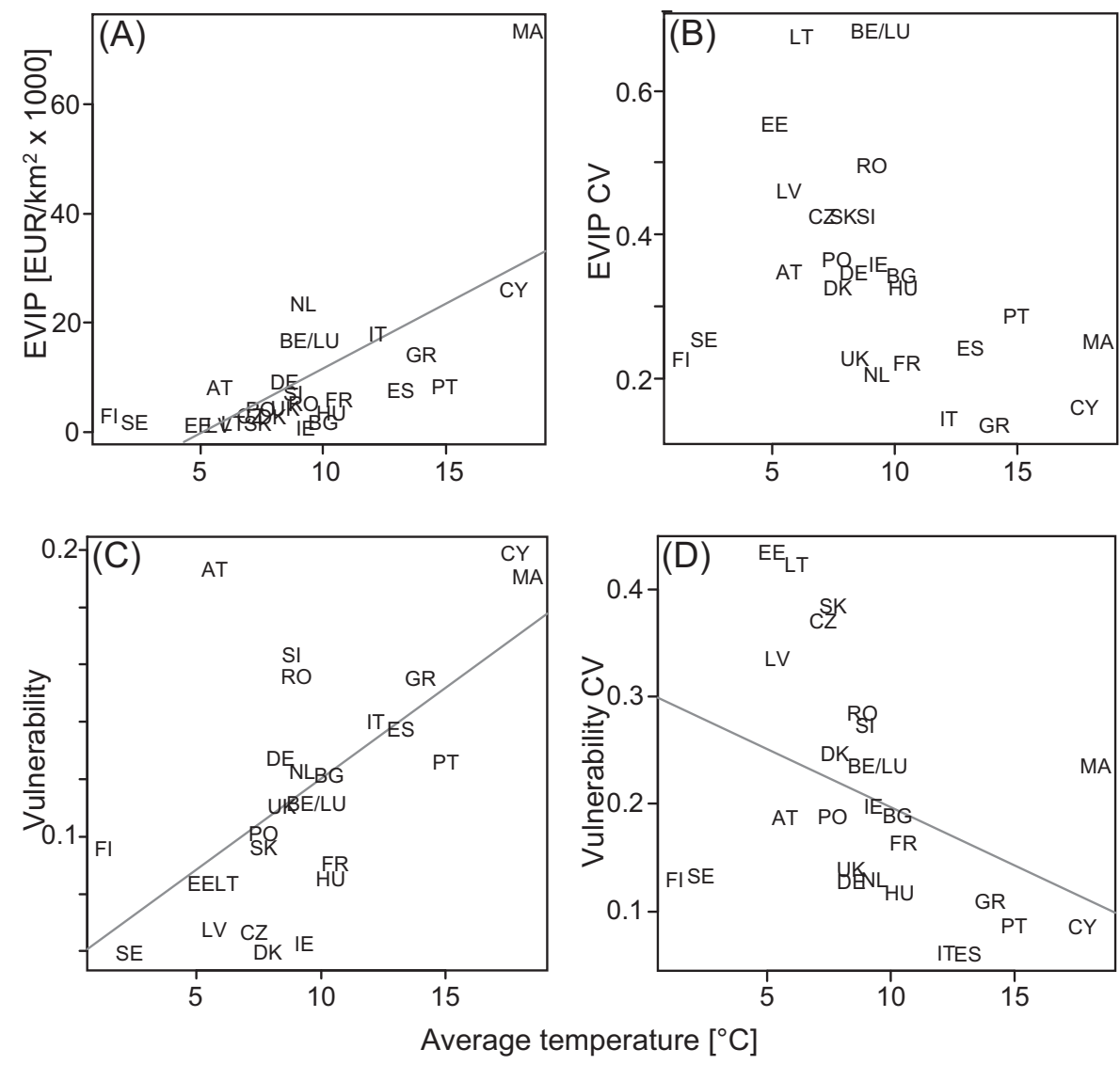

Fig. 3. Economic value of insect pollination (EVIP in EUR/km²) (A) and its variation (CV) (B) as well as the vulnerability (C) and its CV (D) in relation to mean monthly temperature (averaged across the years from 1965 to 1978).

were hitherto lacking for the European Union. Given that economic valuation of ecosystem services is a key tool to facilitate the development of management strategies and policies to optimize the delivery of ecosystem services (Reid et al. 2005), especially in regions that highly depend on pollination (Lautenbach et al. 2012), our paper provides important information for policy decisions and is of interest to the entire society. We show that the economic value of pollination services provided by insects equaled on average $12 \%$ of the total economic value of agricultural production in Europe. The economic gain provided by insect pollinators (EVIP) and hence the overall pollinator dependency of crop production in each country increased from 1991 to 2009 for all but three EU countries. As expected, EVIP and its vulnerability (=proportion of the total gain from agricultural food production) varied strongly among EU countries. The economic value and vulnerability both decreased from warmer to climatically colder EU countries and hence from northern to southern Europe (correlation between latitude and temperature: $r=-0.92$, $p<0.001$ ), with warmer southern countries (particularly Italy and Malta) depending most on pollination services. This finding is in accordance with Lautenbach et al. (2012), who argued that Greece and Italy particularly benefited from insect pollination. Stability of EVIP and vulnerability also increased with a country's gross domestic product derived from the agricultural sector (agricultural GDP). However, these patterns were largely attributable to the four economically strong central and southern countries: Germany, France, Italy and Spain. If these countries were excluded from the analysis, stability of EVIP $(r=0.33, p=0.14)$ and vulnerability $(r=0.39$, $p=0.08$ ) were independent of agricultural GDP, indicating that the economic importance of insect pollination does not necessarily depend on a country's economic strength.

The high dependency on insect pollination of Mediterranean EU countries with their warmer climate is mainly caused by their extensive cultivation of peaches and nectarines where many species depend on bees for pollination (Klein et al. 2007). However, whereas dependency on insect 
pollination increased from the colder north to the warmer south, variation in economic gain from insect pollination decreased, indicating that, compared to northern countries, Mediterranean countries had more stable yields of pollinatordependent crops across years and hence more reliable gains from pollination services. The less stable gains from insect pollination in northern EU countries may in turn be due to larger variations in yields across years. Given that bees are the primary pollinators of most crops produced in Europe (Klein et al. 2007), the greater stability of the economic gain of insect pollination and hence the likely more stable yield in warm countries may partly be explained by higher numbers of wild bee species in those countries. Bee diversity can increase the stability of pollination services due to a higher spatial, temporal or conditional complementarity of species (Blüthgen \& Klein 2011). Moreover, fruit set tends to be higher when crops are pollinated by diverse pollinators instead of just one or a few (Albrecht, Schmid, Hautier, \& Müller 2012; Klein, Steffan-Dewenter, \& Tscharntke 2003). Apples, for instance, likely rely on a variety of pollinating species and not solely on honeybees for full pollination, because they flower early in the year when temperatures can still be low and only few pollinating species (e.g., bumblebees) are active. Depending on the environmental conditions pollinators can further differ in their spatial preferences, with some pollinators preferentially visiting flowers at the upper and outer parts of trees and other the lower and inner parts (Brittain, Kremen, \& Klein 2012). Only a higher diversity of pollinators may hence render the overall service stable enough to overcome seasonal or stochastic fluctuations in populations of single pollinator species (Blüthgen \& Klein 2011; Klein 2011).

Interestingly, the economic gain from pollination services to apples, the most important insect-pollinated crop cultivated in the European Union, did not correlate with temperature ( $r=0.17, p=0.41$ ), but was highest for climatically colder countries, i.e., Belgium, Luxembourg and the Netherlands, where most apples were produced per land area and apples thus accounted for 22\% (Belgium-Luxembourg) and $15 \%$ (Netherlands) of the country's total gain from insect pollination. The economic value of insect pollination of apples was less stable for these major apple producing countries (CV: 0.36-0.44) than for those Mediterranean countries that produce more than on average $1000 \mathrm{t}$ apples/year $(\mathrm{CV}$ : $0.21-0.25)$. As the stability of yields is lower, it is likely that the stability of pollination services is also lower, potentially rendering the stable production of apples in northern Europe at risk. Alternatively, differences in the stability of yields may be explained by differences in spring temperature between southern and northern countries. Relatively cold spring temperatures as well as sudden drops in temperature during the flowering period are more likely to occur in northern than southern countries. In contrast, water shortage may be a problem in southern but not northern countries. However, if orchards are irrigated, water shortage can be compensated for in the Mediterranean counties while temperature will remain a problem in the northern countries, potentially leading to a higher variance in crop yield. Given that apples and citrus fruits were found to be the major providers of vitamin $\mathrm{C}$ for human food supply (Eilers, Kremen, Smith Greenleaf, Garber, \& Klein 2011), they are of high economic and nutritive importance. Ensuring stability of apple production is thus of interest for both economic and human health reasons.

Honeybees, bumblebees, various solitary bee species and hoverflies represent the major pollinators of apple trees (Klein et al. 2007: Appendix 2). Among these pollinator taxa, bumblebees may be of particular importance because they are able to forage at temperatures close to freezing (Goulson 2003) and are therefore active when most other pollinating insects are immobile. However, in recent years, the diversity and abundance of bumblebee species has declined across Europe (Goulson, Lye, \& Darvill 2008) with subsequent changes of the composition of bumblebee communities (Bommarco et al. 2011). The effect of these community changes on the quality of the pollination service by bumblebees has not yet been investigated, but may be significant, and even more so in central and northern Europe where bumblebees have declined most and fewer alternative bee pollinators are present.

We estimated 'vulnerability' to measure the dependency of the agricultural sector, and thus indirectly of our economy, on pollination services. According to the definition proposed by Turner et al. (2003), vulnerability is a function of three elements: exposure, sensitivity and adaptive capacity. Applied to the vulnerability of an economy confronted with pollinator decline, the variable exposure represents the negative impact of pollinator decline, sensitivity represents the intensity of the impact of this decline and the adaptive capacity is the farmers' response to the decline. Gallai et al. (2009) assumed that vulnerability represents a good indicator of a country's dependency on pollination services provided that farmers are able to adapt to changes in pollinator abundance. In this case vulnerability provides a measure of the potential relative production value loss attributed to the lack of insect pollination only. Our results expanded the vulnerability debate since we demonstrated that vulnerability was (indirectly) a function of a country's climatic (temperature), economical (agricultural GDP) and ecological (honeybee abundance and wild bee diversity) variables.

Indeed, given the high importance of pollination services for overall and diverse food production, countries of the European Union face a likely monetary loss due to declining numbers of pollinators. The monetary loss will be particularly pronounced if a country strongly depends on insect pollinator dependent crops that cannot be substituted by other nondependent or less dependent crops. Although it is unlikely that we will lose all pollinating insects, our results can be extended to any level of pollinator decline assuming a positive relationship between fruit set of insect-dependent crops and pollinator density (Clement, Hellier, Elberson, Staska, \& Evans 2007; Dedej \& Delaplane 2003). 
To overcome shortages in wild pollinators, farmers increasingly rely on managed pollinators, such as honeybees. However, honeybees were found to have declined across many European countries for various reasons (Aizen \& Harder 2009; Potts, Roberts, et al. 2010). Our results further indicate that economic gains from pollination may also depend on wild bee species richness. European countries should therefore not rely on a single domesticated pollinator species, but should instead promote policies to provoke greater investments in the conservation of various insect pollinators.

\section{Acknowledgements}

We thank Henrik von Wehrden for help with data analysis as well as an anonymous reviewer and Klaus Hövemeyer whose comments greatly improved our manuscript. SDL is funded by the German Science Foundation (DFG project: LE 2750/1-1) and LAG by UBACYT (20020100300014) and PIP 2012-2014. The study is part of the STEP (Status and Trends of European Pollinators, Grant No. 244090-STEP-CP-FP) funded by the European Commission in the 7th Framework Programmes for Research and Technological Development.

\section{Appendix A. Supplementary data}

Supplementary data associated with this article can be found, in the online version, at http://dx. doi.org/10.1016/j.baae.2013.06.003.

\section{References}

Aizen, M. A., \& Feinsinger, P. (2003). Bees not to be? Responses of insect pollinator faunas and flower pollination to habitat fragmentation. In G. Bradshaw, P. Marquet, \& H. A. Mooney (Eds.), How landscapes change: Human disturbance and ecosystem disruption in the Americas (pp. 111-129). New York: SpringerVerlag.

Aizen, M. A., Garibaldi, L. A., Cunningham, S. A., \& Klein, A. M. (2008). Long-term global trends in crop yield and production reveal no current pollination shortage but increasing pollinator dependency. Current Biology, 18, 1572-1575.

Aizen, M. A., \& Harder, L. D. (2009). The global stock of domesticated honey bees is growing slower than agricultural demand for pollination. Current Biology, 19, 915-918.

Albrecht, M., Schmid, B., Hautier, Y., \& Müller, C. B. (2012). Diverse pollinator communities enhance plant reproductive success. Proceedings of the Royal Society B: Biological Sciences, http://dx.doi.org/10.1098/rspb.2012.1621

Ascher, J. S., \& Pickering, J. (2012). Discover life bee species guide and world checklist (Hymenoptera: Apoidea: Anthophila). http://www.discoverlife.org/mp/20q?guide=Apoidea_species

Banaszak, J. (1995). Changes in fauna of wild bees in Europe. Bydgoszcz, Poland: Pedagogical University.
Biesmeijer, J. C., Roberts, S. P. M., Reemer, M., Ohlemuller, R., Edwards, M., Peeters, T., et al. (2006). Parallel declines in pollinators and insect-pollinated plants in Britain and the Netherlands. Science, 313, 351-354.

Blüthgen, N., \& Klein, A. M. (2011). Functional complementarity and specialisation: Why biodiversity is important in plant-pollinator interactions. Basic and Applied Ecology, 12, 282-291.

Bommarco, R., Lundin, O., Smith, H., \& Rundlöf, M. (2011). Drastic historic shifts in bumble-bee community composition in Sweden. Proceedings of the Royal Society B: Biological Sciences, http://dx.doi.org/10.1098/rspb.2011.0647

Breeze, T. D., Bailey, A. B., Balcombe, K. G., \& Potts, S. G. (2011). Pollination services in the UK: How important are honeybees? Agriculture Ecosystems and Environment, 142, 137-143.

Brittain, C., Kremen, C., \& Klein, A. M. (2012). Biodiversity buffers pollination in changing environmental conditions. Global Change Biology, 19, 540-547.

Brittain, C., \& Potts, S. G. (2011). The potential impacts of insecticides on the life-history traits of bees and the consequences for pollination. Basic and Applied Ecology, 12, 321-331.

Brosi, B. J., Daily, G. C., Shih, T. M., Oviedo, F., \& Duran, G. (2008). The effects of forest fragmentation on bee communities in tropical countryside. Journal of Applied Ecology, 45, 773-783.

Calderone, N. W. (2012). Insect pollinated crops, insect pollinators and US agriculture: Trend analysis of aggregate data for the period 1992-2009. PLOS ONE, 7, e37235.

Cameron, S. A., Lozier, J. D., Strange, J. P., Koch, J. B., Cordes, N., Solter, L. F., et al. (2011). Patterns of widespread decline in North American bumble bees. Proceedings of the National Academy of Sciences of the United States of America, 108, 662-667.

Clement, S. L., Hellier, B. C., Elberson, L. R., Staska, R. T., \& Evans, M. A. (2007). Flies (Diptera: Muscidae: Calliphoridae) are efficient pollinators of Allium ampeloprasum L. (Alliaceae) in field cages. Journal of Economic Entomology, 100, 131-135.

Dedej, S., \& Delaplane, K. S. (2003). Honey bee (Hymenoptera: Apidae) pollination of rabbiteye blueberry Vaccinium ashei var. 'Climax' is pollinator density-dependent. Journal of Economic Entomology, 96, 1215-1220.

Delaplane, K. S., \& Mayer, F. M. (2000). Crop pollination by bees. Wallingford, UK: CABI Publishing.

Eilers, E. J., Kremen, C., Smith Greenleaf, S., Garber, A. K., \& Klein, A. M. (2011). Contribution of pollinator-mediated crops to nutrients in the human food supply. PLoS ONE, 6, e21363.

Gallai, N., Salles, J.-M., Settele, J., \& Vaissière, B. E. (2009). Economic valuation of the vulnerability of world agriculture confronted with pollinator decline. Ecological Economics, 68, 810-812.

Garibaldi, L. A., Aizen, M. A., Klein, A. M., Cunningham, S. A., \& Harder, L. D. (2011). Global growth and stability of agricultural yield decrease with pollinator dependence. Proceedings of the National Academy of Sciences of the United States of America, 108, 5909-5914.

Garibaldi, L. A., Steffan-Dewenter, I., Kremen, C., Morales, J. M., Bommarco, R., Cunningham, S. A., et al. (2011). Stability of pollination services decreases with isolation from natural areas despite honey bee visits. Ecology Letters, http://dx.doi.org/10.1111/j.1461-0248.2011.01669.x 
Ghazoul, J. (2004). Alien abduction: Disruption of native plant-pollinator interactions by invasive species. Biotropica, 36 , $156-164$.

Goulson, D. (2003). Bumblebees: Their behaviour and ecology. New York, USA: Oxford University Press.

Goulson, D., Lye, G. C., \& Darvill, B. (2008). Decline and conservation of bumblebees. Annual Review of Entomology, 53, 191-208.

Hegland, S. J., Nielsen, A., Lázaro, A., Bjerknes, A. L., \& Totland, O. (2009). How does climate change affect plant-pollinator interactions? Ecology Letters, 12, 184-195.

Johansen, C. A. (1977). Pesticides and pollinators. Annual Review of Entomology, 22, 177-192.

Klein, A. M. (2011). Plant-pollinator interactions in changing environments. Basic and Applied Ecology, 12, 279-281.

Klein, A. M., Steffan-Dewenter, I., \& Tscharntke, T. (2003). Fruit set of highland coffee increases with the diversity of pollinating bees. Proceedings of the Royal Society of London Series B: Biological Sciences, 270, 955-961.

Klein, A. M., Vaissiere, B. E., Cane, J. H., Steffan-Dewenter, I., Cunningham, S. A., Kremen, C., et al. (2007). Importance of pollinators in changing landscapes for world crops. Proceedings of the Royal Society B: Biological Sciences, 274, 303-313.

Kremen, C., Williams, N. M., Aizen, M. A., Gemmill-Herren, B., LeBuhn, G., Minckley, R., et al. (2007). Pollination and other ecosystem services produced by mobile organisms: A conceptual framework for the effects of land-use change. Ecology Letters, 10, 299-314.

Kremen, C., Williams, N. M., \& Thorp, R. W. (2002). Crop pollination from native bees at risk from agricultural intensification. Proceedings of the National Academy of Sciences of the United States of America, 99, 16812-16816.

Kuhlmann, M. (2012). A checklist of the western Palaearctic bees Current state and the role of professional amateurs. Mitteilungen des Entomologischen Vereins Stuttgart, 47, 15-16.

Kuhlmann, M., Ascher, J. S., Dathe, H. H., Ebmer, A. W., Hartmann, P., Michez, D., et al. (2012). Checklist of the Western Palaearctic bees. http://westpalbees.myspecies.info (accessed 30.06.12)

Lautenbach, S., Seppelt, R., Liebscher, J., \& Dormann, C. F. (2012). Spatial and temporal trends of global pollination benefit. PLoS ONE, 7, e35954.

McGregor, S. E. (1976). Insect pollination of cultivated crop plants. Washington, DC, USA: Agricultural Research Service, U.S. Dept. of Agriculture.
Miller, J. A. C., Henning, L., Heazlewood, V. L., Larkin, P. J., Chitty, J., Allen, R., et al. (2005). Pollination biology of oilseed poppy, Papaver somniferum L. Australian Journal of Agricultural Research, 56, 483-490.

Potts, S. G., Biesmeijer, J. C., Kremen, C., Neumann, P., Schweiger, O., \& Kunin, W. E. (2010). Global pollinator declines: Trends, impacts and drivers. Trends in Ecology \& Evolution, 25, 345-353.

Potts, S. G., Roberts, S. P. M., Dean, R., Marris, G., Brown, M., Jones, R., et al. (2010). Declines of managed honeybees and beekeepers in Europe. Journal of Apicultural Research, 49, 15-22.

Quintero, C., Morales, C. L., \& Aizen, M. A. (2010). Effects of anthropogenic habitat disturbance on local pollinator diversity and species turnover across a precipitation gradient. Biodiversity and Conservation, 19, 257-274.

R Development Core Team. (2012). R: A language and environment for statistical computing. Vienna: R Foundation for Statistical Computing. http://www.R-project.org

Reid, W. V., Mooney, H. A., Cropper, A., Capistrano, D., Carpenter, S. R., Chopra, K., et al. (2005). Ecosystems and human wellbeing: A report of the millennium ecosystem assessment (Synthesis). Washington, DC: Island Press.

Schweiger, O., Biesmeijer, J. C., Bommarco, R., Hickler, T., Hulme, P. E., Klotz, S., et al. (2010). Multiple stressors on biotic interactions: How climate change and alien species interact to affect pollination. Biological Reviews, 85, 777-795.

Steffan-Dewenter, I., Potts, S. G., \& Packer, L. (2005). Pollinator diversity and crop pollination services are at risk. Trends in Ecology \& Evolution, 20, 651-652.

Steffan-Dewenter, I., \& Tscharntke, T. (1999). Effects of habitat isolation on pollinator communities and seed set. Oecologia, 121, 432-440.

Thomas, J. A., Telfer, M. G., Roy, D. B., Preston, C. D., Greenwood, J. J. D., Asher, J., et al. (2004). Comparative losses of British butterflies, birds, and plants and the global extinction crisis. Science, 303, 1879-1881.

Turner, B. L., Kasperson, R. E., Matson, P., McCarthy, J. J., Corell, R. W., Christensen, L., et al. (2003). A framework for vulnerability analysis in sustainability science. Proceedings of the National Academy of Sciences of the United States of America, 100, 8074-8079.

Winfree, R., Aguilar, R., Vazquez, D. P., LeBuhn, G., \& Aizen, M. A. (2009). A meta-analysis of bees' responses to anthropogenic disturbance. Ecology, 90, 2068-2076.

Available online at www.sciencedirect.com

\section{SciVerse ScienceDirect}

